\title{
Drawbacks of Alternative Media in Development: Bangladesh Context
}

\section{Amir Mohammad Khan}

Lecturer of English, Feni University Email: amir_khan.chu@yahoo.com

Nur-E-Makbul

Lecturer, Dept. of Journalism, Communication and Media Studies, State University of Bangladesh

\section{Doi:10.5901/mjss.2014.v5n23p2229}

\section{Abstract}

This article is all about the real face of Development, Alternative Media (AM), Drawbacks of AM in the context of Bangladesh. Organizations like UN who work for Development are not in the right track since they deny problems like 'poverty' and 'hunger' as parts of Development. As a result, their projects start and end without any mentionable Development. Most experts include internet to be an AM but folk media like opera and doll-dancing never get priority. But these are found to be more effective for Development. After 90's Internet evolved in our country that is a New Media (NM) but is not again effective since till date the percentage of internet users is very low. In the NM like Internet the voice of labour class never gets focus and that's why it is not universal. In the NM like Facebook, Blog we see the active participation of general people and they can easily raise voice in favour or against any issue. But these cannot play mentionable role in Development. Various arguments like Mujib-Zia, LeftRight etc prove that AM is for Development, Development is not for the AM. Development comes through some root level people like farmers not through AM. Certain TV Shows like 'Hridoy e Mati o Manush' (Earth and man in Heart) proves that they misguide the Development stakeholders. The use of difficult words by the Development workers somehow creates a hindrance on the way to Development. Folk media like songs of Sufia, doll-dancing are more effective for Development than the so-called AM like internet. Whereas internet covers a small portion of nation, folk media covers a larger portion but the matter of fact is that folk media never reaches the ears of policy makers. That's how AM cannot come out of its drawbacks and we need to think newly with the NM and way to Development.

Keywords: Alternative Media, Development, Drawbacks, Folk Media, New Media.

\section{Introduction}

Leaving aside the literal meaning We wanted to define the 'Development' in the light of general students' thinking of the University of Dhaka. Those who were interviewed grossly opined 'Development' to be the positive advancement of poverty, hunger, education, gender, environment sustainbility, ensuring fundamental rights etc. The wondering fact is that there is a special similarity between general students' opinion and mentioned facts in the millennium development goals (MDG) of United Nations-2000. In this sense two things are visible. One, media to define last 12 (twelve) years' 'Development' by reproducing these things, newly played special role in creating some kind of idea in the mind of general people. Second, in the current world circumstances most people are considering these things as problems and to get rid of these problems is marked as 'Development' by them.

\section{2. "Development"-Phenomenon (D-P)}

Needn't say, to define is easier to understand in the D-P. Recently those organizations of United Nations who are working for 'Development'; We feel they also find it complex to define phenomenon. We think the real print of D-P is embedded in two words: 'Disparity Eradication' or 'Establishment of Equity'. It is possible to understand all above mentioned things in these two words. And it is also true that because of pervasive disparity in the society 'Hunger' and 'Poverty' is increasing every day. Obviously, though there is a connection between D-P and the words-disparity, equity, the Development seeking NGOs knowledgably deny these words. Because these words are more political than literal. But, UN or mainstream media all are leaving aside these pair of words representing a model worldwide in the name of 'Development' which I want to call 'Development Trade'. My words in this way will be clarified in the further discussion. 


\section{Alternative Media (AM)}

Now, let's talk about AM. It is said, since the beginning of evolvement of Journalism Profession there were the existence of AM. In discussing the evolvement of UK media in the narration of Jean Seaton and James Karan we could know about 'Radical Press' or one kind of worker class that is marked by these two researchers as AM. In identifying the nature of AM things that came to our eyes are: 1. The AM advocates for the change of society.2. The AM is not profit earning. 3. It challenges the containing power structure of the society. 4. It works for establishing right of the labour class or general people in reverse to producing ethics in favour of ruling organization of the society. In the discussion of Professor Fahmidul Huq we observe such kind of AM (eg: Indimedia, Genet etc.). He thinks, in that line except some leftist newspapers in Bangladesh (eg: Vanguard) no AM is found. Dr. Fahmid in his discussion to define AM is keeping eyes on cyber space. But, we opine differently. If Poster, street play, Opera, Narrative or Doll Dancing-these kinds of folk media contains above mentioned characteristics, then we would like to include these media in the AM as well. Because, we personally believe, in the AM of internet based cyber space, the pleasure and accession of our root level people is not satisfactory. But these folk media can reach us comparatively easily. As a result, what we think is, in the discussion of AM these folk media in no way can be kicked off. Moreover, these folk media is stronger and easily accessible than the internet based AM.

\section{The New Media (NM)}

In this context we need to clarify one thing. After the decade of 90 the NM on internet became popular and this is comparatively more technology based. We think, the NM and AM is not similar rather AM is a part of NM. Again, if we consider the internet based social communication media to be $A M$, in this sense, the question of profit earning tendency of these media arises. Because, nowadays in the popular communication sites the access of advertisements and cheating of animation like advertisements come to eyes very easily. As a result, in that sense, these media cannot be considered under the criteria of James Karan and Jean Seaton. Even then, because of class partiality the news that cannot come to mainstream media; we watch their public sphere in cyber space. In addition to that, innovation is done on the advertisement dependant online newspapers as well. These online newspapers though in that sense shouldn't be considered AM at all. Yet, in these media recently there are opportunities for readers to opine. That means one part of mainstream media (PrintMedia and Online) is again characteristically somehow following the AM. For example, if we consider the letter-column part of print media and readers' opinion part of online newspapers then this thing will be clear. Now if reader wants he/she can appropriately present his/her arguments beneath the online news of 'Prothm-alo' not supporting the news in favour of his/her opinion. As a result in this media an opportunity for everyone to opine is being generated and it is also playing one kind of role in breaking the power-structure of the society. The question that came before and still arises is, this internet based media is accessible to what percentage of men? It is not yet accessible to the labour class of the society. So, in this internet based media the voice of the labour class is not directly coming rather their voice is deconstructed (Deconstructed Proletariat Voice) there. To evaluate the role of AM in the cyber space and to develop the society, we feel the necessity of making the class of internet users in Bangladesh. In the survey it is stated, in Bangladesh less than $1 \%$ or close to $1 \%$ people enjoy the internet facility. So habitually it is clear that this modern science and technology is not at all neutral in our society. That means the readers, writers, opinion makers of AM none leads that class basically whose Development is most important at this moment. So, those of us who are talking about Development in cyber space should understand that this is an alienated public sphere.

\section{When Others Become More Interested in Someone's Business, While He is Not}

A proverb goes in Bengali, "When others become more interested in someone's business, while he is not". The Development of Bangladesh through AM in the cyber space is pretty much contextual with this proverb. This can be clarified by an example. When the manuscript of 'Information Right Law' came into light in our country then the number of internet users was about $0.5 \%$ in the country. And the members of this manuscript act making class were the valuable monitors of NGO or elite class in the society. But, the manuscript was created to ensure the right of general citizens of the society sothat they can get sufficient information. So, for who the development is, without their participation can anything in any case be told 'Development'? Needn't say, internet based AM specifically fails in this place. This media cannot abridge the gap between general people and policy makers. Development can be of different kinds through AM. For the sake of argument if we even assume AM is changing the mentality of a small group (the internet user group). Many people say AM is playing role to create awareness and establish voice among people against Border killing, Tipaimukh 
dam, Corruption and other social problems. But we could realize the issue differently. Our question is, could this awareness at all play mentionable role in policy making? This issue can be more clarified. We observed a kind of storm in the social sites: Facebook, Blog etc regarding the issue of Padma River Bridge corruption case, the immature talk of current Home Minister about law and order situation, argument about Dr. Md. Yunus etc. But if we deeply think the objective of these arguments in cyber space we see it is more political than social. Those who are raising voice against the government regarding the social development now, lately they will sleep in case they form the government. Their main headache doesn't center around 'Poverty Alleviation' whether it is being implemented or not or how much it is implemented; rather their discussion is confined to explaining their strong oneness regarding respecting or disrespecting Dr. Yunus. None has any tension regarding how much the Development of rural people is done. Through this in the Development the failure picture of AM becomes clear.

\section{The Spiral of Silence}

The 'Spiral of Silence' by the specialist Elizabeth Noelle-Newmann is effective in both social communication media and AM. The Development issues are getting defocused because of issues like the voice against BNP-Awami ideal, the savage scolding of believer-agnostic, conflict of Left and Right, Mujib-zia conflict etc. As a result, the role of AM in Development is again under question. The drawback that needs mention is, if we see Development and AM in the light of cause-effect relationship of Economics the thing we see, that is in brief-"AM is for Development, Development is not for $A M$ ". That's why there is no logic in presuming that Development is not possible without AM. The recent Arab Spring is called the flawless outcome of NM by many people. But, We believe when we give main credit of Arab Spring to social communication sites leaving aside one hero Khalid or hundreds-thousands democracy expecting people, in that case, really it becomes like humiliating the contribution of these democracy seeking people. We won't hesitate to say, in this revolt there was the contribution of Information-Technology (IT). But if the general people didn't congregate together in Tahrir Squad, in that case, the Arab Spring couldn't create response worldwide. In this connection what we must confess is, Arab Spring was the outcome of long awaited explosion of resentment of millions of democracy seeking people. The writer Ronesh Dasgupta in his writing while explaining 'Marxist Attitude and Historical Conflicting Materialism' mentions our war of freedom to be likewise 'Explosion of Long Awaited Resentment'. In the Arab Spring the AM was one of the gearing powers to help accelerate the revolt only. If we analyse the perspective of war of freedom of Bangladesh too we see the same scenario though during the war in 1971 there was no use of cyber space; that's why there remained no question of AM. But, we believe, there is no greater Development than to get emancipation from long-term exploitation and wretchedness. So, for Development the strength of man's will power is solely the main thing, not the AM. In the context of Development we must talk about Amartya Sen. Sen is not directly talking about the Development, he says, 'Capability and Development'. He abstained himself from participating in talking in favour of any dogma like the Researchers of School of Development. We personally agree with what Sen says. Because, if he who will indulge himself growing crops in the field and eradicate hunger-poverty cannot find happiness in agriculture, in that case Development is not possible for him in this work. So, for Development the personal creativity of Development seeking people is important, AM is not main thing here. AM can keep up the picture of Development only, but cannot directly play role in the process of Development.

\section{Trade in Heart}

To analyse the context of Bangladesh we can mention one example. In the television show like 'Earth and Man' the farmers are instigated to use hybrid seed fertilizer for better harvest. In reality, farmers are certainly getting better harvest from these seeds; but the customers are not buying rice of those kinds. As a result, farmers are losing their rice market and facing economic losses. Many satirizes in this way: the real character of those social media bearing slogan, 'Earth and Man in Heart' is actually 'Trade in Heart'. As a result, the real picture is never shown in this channel. In this case we think the AM can play strong role. But again the question arises;-could the AM reach farmers? Suppose some left idealist newspapers like 'Vangaurd' reached the farmers. In this case there can be seen two problems; 1 . The educational qualification of Development seeking people will keep them apart from AM. 2. Our left idealist organizations still cannot come out of their practice of using difficult words. (eg: opposition, power, colonial power, imperialistic power etc-these words are we consider complicated to the Development seeking people). They may fail to make understand the meaning of Development to the general people. That means, with the daily changing knowledge and technology daily changing proficiency is important. That's why, in Development the communication proficiency of AM users is more important than the medium. In our country now because of the cell phone companies internet is spread to villages-towns. But, this 
service we think is still unable to play role in Development. Apart from changing technology with the lack of changing proficiency another thing is now drawing more attention that is-'Ethics'. Technology itself doesn't understand ethics. My question lies on ethics and feeling of users. If the Development seeking young people of the village not watching Development news get indulged in local or foreign product addiction, in that case the possibility of Development will also decrease.

\section{Drawbacks of Alternative Media}

It is questionable, why the AM cannot contribute to the Development? I think one reason is-specific organizational structure and lack of work-system. Recently in Shatkhira the news of minority exploitation didn't came to focus in the mainstream media. But, in the Youtube and Facebook under the heading of 'Didn't We Sing Your National Anthem?' draws attention of all. Though the mainstream media overlooked this issue we saw the real incident in the cyber space. This is of course the possibility of AM. But, the matter of wonder is that the very next day of this post of videofilm it is found no more. The organizational structure and functional drawback of AM is realized from this factor. Another drawback of AM is the lack of longer-lasting span (AM doesn't think for long-term sustainability). For any kind of Development longterm planning is a must. It is found in the research; those who work for Development in our country they at best think of five years, implement projects and work in the field. The same scenario is seen in the AM. As long as one incident ends another takes place, and our AM also moves its focus elsewhere. As a result, the possibility of strong Development is interrupted. Suppose, in the Monga affected area of Northern part of Bangladesh one NGO works for five years under 'Mother's Breast Feeding Consciousness' Project. For this they announce a good amount of fellowship for media workers. Then they provide trainings in their own style and give instruction about covering the news. Here is basically the harsh negligence. Not considering the fact how successful the project is, after doing 5-10 reports it is said-'The project implementation is successful'. The real scenario is different. Consequently, when the mainstream media is unable to reach, AM will work for Development there; in the context of Bangladesh this matter is quite a daydream. At least in these rural Development projects AM is quite unable to play role.

\section{Folk Media and Alternative Media (AM)}

At the beginning of discussion we already said, "if poster, street play, opera, narrative or doll dancing-these kind of folk media contains above mentioned characteristics then we would like to include these media in the AM as well. Because we personally believe, in the AM of internet based cyber space, the pleasure and accession of our root level people is not satisfactory. But these folk media can reach us comparatively easily". Can we call the folk media to be AM? We believe, certainly. Whatever the name is-folk or alternative, there is no function of the name. In the above mentioned Monga affected northern part of Bangladesh regarding the 'Mother's Breast Feeding Consciousness Project' we believe the folk media undoubtedly will be able to play positive role. In the context of this media if the Development issue is placed and then in the local dialect if it is sent to the people, then Development will be possible to a great extent. In the flawless creation by late Tareque Masud the film of 'Matir Moyna' one street play like this represented to us the thousand years' picture of rural Bangla. The context of the song was 'Non-communalism relationship between man and woman', 'Patriarchal politics' etc. We deny the fact that one should read 'Virginia Wolf' or 'Mary Wolstonecraft' to understand patriarchal politics and right of woman. We are doubtful how much of the educated women among the society memorized 'Oborodbashini' by Begum Rokeya! We think regarding this Kangalini Sufia is slightly more successful. Her easy-lucid lyric, tune of soil very easily can attract the rural people of our country. In the song of Kangalini she advocates for changing the society, persuades people to break the power structure of the society; in that case why we won't call her song to be AM? Under these considerations the Subaltern Voice is also a strong AM to us. But, the main problem lies in another place. Can this Subaltern Voice at all break the power structure of the society? Their voice never gets minimum importance in the policy-making of king-queen. As a result, AM or Subaltern Voice whatever the name is, none of them is free from drawbacks. In the context of poster that advocates for the change in society; if that doesn't have profit-earning purpose; in that case the poster can be considered an AM. But there will be a great drawback with poster. That is. If the Development seeking people fail to understand the language of poster then the communication will be interrupted. Some interruptions happen in case of cartoon or satirical picture. Again suppose, by the doll dancing you will represent the matter of nursing mother and baby. For the development of rural people this matter is very important. But drawbacks remain alive still. The Development seeking people watch the doll dancing as a recreation only. It is difficult to think that after watching the dance and knowing this matter they will be conscious regarding the nursing of mother-baby, their nutrition etc. So, if we consider the folk media like doll dancing to be AM, yet there is still drawbacks. 


\section{Conclusion}

If we want to arrange our disordered discussion, in that case the main tune comes in this way-'AM is for Development only; Development is not for the AM'. It is easier to recognize and understand the word-'Development' than to define it, and this word is of course political. The word 'Development' itself wants to hide its character. For example, by introducing 'Adult Education' in the name of rural development the part in power wants to hide the failure of ensuring the right of education. And if we analyse the characteristics of AM in this context there won't be found any strong AM in Bangladesh at all. Though our specialists of people's media marked cyber space, internet and some dogmatic bulletin in discussing AM, I spontaneously tried to explain some folk media in the light of the characteristics of AM and tried to delineate their drawbacks in Development. The detachment of Development seeking people from internet and the $1 \%$ people's using internet in the cyber space is sought to be marked as drawbacks by us. In the cyber space under the name of Development, scolding of believer-agnostic and because of the two party centered Mujib-Zia argument the issues of Development are being hidden beneath like 'Spiral of Silence' that to us is a hindrance for AM on the way of possibility. Those sites which characteristically somehow support AM, there is 'Gate keeping' too. For this reason, incidents like noncommunal battle in Shatkhira vanish within few days. And again those who really want to raise voice for general people, their complexity of choice of words kept themselves distant from Development seeking people. If we even presume the lower class voice like 'Kangalini Sufia' to be AM for the Development of the society, in that case these voice of drilling wall can never reach the policy-makers. Likewise, the revolt of cyber space against disparity cannot play mentionable role in policy making. The AM like doll-dancing contains elements of Development and social change that is received by the people as recreation only; not in the purpose of becoming conscious. So for the folk media to be on the way of possibility of being AM, this one is to us the main hindrance. Therefore, in the context of Bangladesh the functioning relationship of AM, lack of specific organizational foundation, lack of long-term Development policy etc and by marking the drawbacks of AM in Development we wanted to represent our words to the readers.

\section{References}

Chowdhury, Rafiqul Huda, "Achieving Millennium Development Goals on Maternal and Child Health in Rural Bangladesh: Lesson learnt from GK Programme Villages." Paper presented in a seminar at the Bangladesh Institute of Development Studies (BIDS), Dhaka, 10 May 2006.

Paul keen (2003), "The Popular Radical Press in Britain, 1811-1821". A Reprint of Early Nineteenth-Century Radical Periodicals. Retrieved from http://www.pickeringchatto.com/titles/1216-9781851967520-popular-radical-press-in-britain-1811-1821

Pieter Boeder, Habermas Heritage: the future of the public sphere in the network society, 20 March, 2011 and retrieved from http://devika84.wordpress.com/2011/03/20/emac-6300-devika/

Karan, James and Jna Setan (2003). Power without responsibility: the press, broadcasting and news media in Britain. London: Routledge.

Huq, Fahmidul (2011). Alternative Media. Communication Newspaper. Number: 10.

Noelle-Neumann, E. (1984). The Spiral of Silence: Public Opinion-Our Social Skin. Chicago: University of Chicago.

Ananya Raihan, "Tothyo Odhikar Ain: Trinomuler Konthoshhor", presented at a seminar organized by MRDI, Dhaka, 23 September 2010.

Tremaen, Edited by Mark (2007). 'B-ging, Citizenship and the Future of Media'. NewYork: Rightledge.

Bell, David (2001). 'An Introduction to Cyberculture'. London: Routledge.

Singhal, Orobinda and Sweet Law (2001). 'The Present, Past and Future of Development Communication: The Conversation with Everett M Rogers'. Translated by A Al Mamun. Communication, No. 3.

Atton, Chris. 2011. Approaching Alternative Media: Theory and Methodology. Our Media. Web: www.ourmedianet.org

Warschauer, Mark, 2004.Technology and Social Inclusion: Re-thinking the digital divid.Cambridge: The MIT Press.

Rogers, Eveett M.1962. Diffusion of Innovation. New York: Free Press.

Sainath, P. 1966. 'Everybody Loves a Good Drought'. New Delhi: Penguine Books India. 